\title{
A new hermit crab of the Paguristes tortugae complex (Crustacea: Anomura: Diogenidae), with a key to the western Atlantic species
}

\section{Daniel José Marcondes Lima \& William Santana}

To cite this article: Daniel José Marcondes Lima \& William Santana (2017) A new hermit crab of the Paguristes tortugae complex (Crustacea: Anomura: Diogenidae), with a key to the western Atlantic species, Marine Biology Research, 13:2, 220-228, DOI: 10.1080/17451000.2016.1239021

To link to this article: https://doi.org/10.1080/17451000.2016.1239021

曲 Published online: 12 Jan 2017.

Submit your article to this journal $₫$

Џ Article views: 179

View Crossmark data $\complement$ 


\title{
A new hermit crab of the Paguristes tortugae complex (Crustacea: Anomura: Diogenidae), with a key to the western Atlantic species
}

\author{
Daniel José Marcondes Lima (10,b and William Santana (10) \\ aprograma de Pós-Graduação em Zoologia, Universidade Estadual Paulista, UNESP Campus Botucatu, Botucatu, Brazil; 'baboratório de \\ Sistemática Zoológica, Pró-Reitoria de Pesquisa e Pós-graduação, Universidade do Sagrado Coração - USC, Bauru, Brazil
}

\begin{abstract}
A new hermit crab species, Paguristes scarabinoi sp. nov. is described and illustrated based on specimens collected in Uruguay. The new species is assigned to the Paguristes tortugae species complex based on the characteristic dense fringe of long plumose setae present on ambulatory legs and dorsolateral margins of chelae. The new species can be differentiated from all other species currently placed in the $P$. tortugae complex by the combination of the following features: antennal flagellum with short and long setae on each article; antennular peduncles short to moderately long, not exceeding one-third of ocular peduncles including the corneas; dactyl of ambulatory legs long, slender, slightly convex and without a longitudinal sulcus flanked by corneous spines or spinules on the mesial face; and female brood pouch elongate, slender, blade-shaped. A key to the western Atlantic species of the $P$. tortugae complex is provided.
\end{abstract}

http://zoobank.org/urn:Isid:zoobank.org:pub:4B3298F3-D5DF-40E5-A2AB-9B457AB8BE0E

\section{ARTICLE HISTORY}

Received 12 June 2016

Accepted 13 September 2016

Published online 12 January

2017

\section{RESPONSIBLE EDITOR}

Roy Kropp

\section{KEYWORDS}

New species; Paguroidea; South America; southwestern Atlantic; Uruguay

\section{Introduction}

The taxonomic knowledge of several western Atlantic genera of the large decapod superfamily Paguroidea is still unsatisfactory, mainly because of deficient, incomplete or confusing taxonomic and distributional data for many common species (Lemaitre \& Tavares 2015). Paguristes Dana, 1851 is one of the most species-rich among the paguroid genera and the first in number of species in the Diogenidae, with 131 species (WoRMS 2016). In the western Atlantic, 34 species are currently assigned to Paguristes, in which several complexes of closely related species have been proposed. Published and ongoing studies show that many cryptic, undescribed species remain to be documented in the $P$. tortugae complex (McLaughlin \& Provenzano 1974, 1975; Lemaitre \& Felder 2012; Rafael Lemaitre 2016, personal communication).

Species of the Paguristes tortugae Schmitt, 1933 complex can be readily distinguished from other western Atlantic congeners by the presence of a distinct, dense fringe of plumose setae bordering the ambulatory legs and dorsolateral margins of the chelae (McLaughlin \& Provenzano 1974). Eight species are currently recognized in this complex: P. angustithecus McLaughlin \& Provenzano, 1974;
P. anomalus Bouvier 1918; P. hernancortezi McLaughlin \& Provenzano, 1974; P. maclaughlinae Martínez-lglesias \& Gómez, 1989; P. perplexus McLaughlin \& Provenzano, 1974; P. tortugae Schmitt, 1933; P. werdingi Campos \& Sanchez, 1995; and P. zebra Campos \& Sanchez, 1995. Herein we describe the ninth species of the $P$. tortugae complex, Paguristes scarabinoi sp. nov. based on material from Uruguay and provide a revised key for the western Atlantic species of this complex.

\section{Materials and methods}

The type material was collected by the Uruguayan research vessel 'Aldebaran', on Cruise 2005/04 between $35^{\circ} 41^{\prime} 7^{\prime \prime} \mathrm{S}-52^{\circ} 35^{\prime} 6^{\prime \prime} \mathrm{W}$ and $34^{\circ} 43^{\prime} 1^{\prime \prime} \mathrm{S}-52^{\circ}$ $37^{\prime} \mathrm{W}$, on 12 November 2005. Specimens were collected with a small dredge attached to an Engel Otter Trawl, at 66-68 $\mathrm{m}$ depth and fixed with $5 \%$ buffered formalin. Type specimens are deposited in the crustacean collections of the Museum of Zoology of the University of São Paulo, São Paulo, Brazil (MZUSP), and the Muséum national d'Histoire naturelle, Paris, France (MNHN). Terminology used mostly follows Provenzano (1959) and McLaughlin \& Provenzano (1974). Shield length (sl) was measured in millimetres $(\mathrm{mm})$ from the

CONTACT Daniel José Marcondes Lima danieljmlima@gmail.com $Q$ Laboratório de Sistemática Zoológica, Pró-Reitoria de Pesquisa e Pós-graduação, Universidade do Sagrado Coração - USC, Rua Irmã Arminda, 10-50, Jd. Brasil, 17011-160 Bauru, SP, Brazil

(c) 2017 Informa UK Limited, trading as Taylor \& Francis Group 
mid-point of the rostral lobe to the mid-point of the posterior margin of the shield. Other abbreviations include: stn for station and coll. for collector. Drawings were made using a Leica MZ12S stereo microscope equipped with camera lucida.

\section{Comparative material}

Paguristes robustus Forest \& de Saint Laurent, 1967: MZUSP 12195, male sl $6.2 \mathrm{~mm}$, female sl $3.0 \mathrm{~mm}$, Rio de Janeiro, Angra dos Reis, stn 102, 1 July 1966, $21 \mathrm{~m}$. MZUSP 18633, female sl $4.8 \mathrm{~mm}$, Brazil, São Paulo, Ubatuba, March 2001, $35 \mathrm{~m}$. MZUSP 12196, male sl $3.1 \mathrm{~mm}$, Rio Grande do Sul, stn $1643,33^{\circ} 46^{\prime} \mathrm{S}, 53^{\circ}$ 17'W, PROJETO GEDIP coll., 16 January 1972, $15 \mathrm{~m}$. MZUSP 13323, ovigerous female sl $5.5 \mathrm{~mm}$, Rio Grande do Sul, stn $1643,33^{\circ} 46^{\prime} \mathrm{S}, 53^{\circ} 17^{\prime} \mathrm{W}$, PROJETO GEDIP coll., 16 January 1972. MZUSP 9398, female sl $6.0 \mathrm{~mm}$, Rio Grande do Sul, stn $1643,33^{\circ} 46^{\prime} \mathrm{S}, 53^{\circ}$ 17'W, PROJETO GEDIP coll., 16 January 1972.

Paguristes tortugae Schmitt, 1933: MZUSP 34275, male sl 3.5 mm, female sl $3.0 \mathrm{~mm}$, Panama, Bocas de Toro, Isla Colón, Punta Caracol, stn 3, A. Anker et al. coll., 27 April 2015, 0.5-2.0 m. MZUSP 34226, male sl $3.8 \mathrm{~mm}$, Bocas del Toro, J. Vicente Raczkowsli coll., July 2015. MZUSP 9381, male sl $7.0 \mathrm{~mm}$, male sl $6.8 \mathrm{~mm}$, Brazil, São Paulo, Ubatuba, stn Base do Instituto Oceanográfico, João Candeias coll., February 1986.

\section{Taxonomy}

Family Diogenidae Ortmann, 1892

Genus Paguristes Dana, 1851

Paguristes scarabinoi sp. nov.

(Figures 1-5)

\section{Material examined}

Holotype. MZUSP 34621: male sl $4.0 \mathrm{~mm}$, southwestern Atlantic, off Uruguay, between $35^{\circ} 41^{\prime} 7^{\prime \prime} \mathrm{S}$ $52^{\circ} 35^{\prime} 6^{\prime \prime} \mathrm{W}$ and $34^{\circ} 43^{\prime} 1^{\prime \prime} \mathrm{S}-52^{\circ} 37^{\prime} \mathrm{W}$, R/V 'Aldebaran', stn L.4, 66-68 m, Fabrizio Scarabino coll., 12 Nov. 2005.

Paratypes. Same locality as holotype. MZUSP 34625: male sl $3.7 \mathrm{~mm}$ (dissected); male sl $3.2 \mathrm{~mm}$; male sl $2.9 \mathrm{~mm}$; male sl $2.6 \mathrm{~mm}$; female sl $2.0 \mathrm{~mm}$. MNHN-IU2014-12855: male sl $3.3 \mathrm{~mm}$; female sl $2.4 \mathrm{~mm}$ (first pleopod detached), male sl $1.9 \mathrm{~mm}$.

\section{Diagnosis}

Antennal flagella with irregularly short and long setae on each article, of 1-6 articles in length. Antennular peduncles short to moderately long, to about or reaching about one-third of ocular peduncles including the corneas. Ambulatory legs and dorsolateral margins of the chelae bordered by a distinct and dense fringe of plumose setae. Dactyl of ambulatory legs long, slender, slightly convex and mesial margin of ambulatory legs devoid of setae. Female brood pouch elongate, slender, blade-shaped.

\section{Description}

Thirteen pairs of biserial gills. Shield (Figures $1 \mathrm{~A}$ and $5 \mathrm{~F}$ ) slightly longer than broad; dorsal surface moderately rugose, on anterior branchial regions with scattered long tufts of setae; dorsolateral surfaces and margins with scattered tufts of long setae, with small spines or spinules. Anterolateral margins sloping. Anterior margins between rostrum and lateral projections concave. Posterior margin truncate. Rostrum long, usually exceeding lateral projection, acutely triangular, margins with tufts of long plumose setae. Lateral projections moderately prominent, obtusely triangular or rounded. Posterior carapace mostly membranous, posteromedian plate with transverse row of long plumose setae, branchiostergite with dense tuft of long plumose setae on anterior margins.

Ocular peduncles (including corneas) long, about 0.6 times length of shield, subcylindrical; dorsomesial surface with tufts of moderately long setae, tufts of long plumose setae proximally; corneas slightly dilated. Ocular acicles subtriangular; mesial margins strongly sloping, nearly parallel, lateral margins weakly sloping; terminating in trifid spine; separated basally by less than basal width of 1 acicle.

Antennular peduncle three-segmented, reaching or almost reaching distal margin of corneas in full extension. Ultimate and penultimate segments with few scattered setae on dorsal and mesial surfaces. Basal segment with prominent short spine on ventromesial distal angle; lateral margin with acute spine distally and 1 short spine proximally.

Antennal peduncle not exceeding proximal margin of corneas, with supernumerary segmentation. Fifth segment with scattered, moderately long setae on ventral surface. Fourth segment with small spine on dorsodistal margin and one tuft of short setae on ventral surface. Third segment with distoventral margin strongly produced, ending in acute spine; mesial margin with 1 small spine. Second segment with distal dorsolateral angle produced, terminating in broad bifid spine; lateral margin with 3 or 4 accessory spines, with dense tufts of long plumose setae; dorsomesial distal angle with small spines, with few tufts of long setae. First segment with ventrodistal margin produced; 1 or 2 small spines on lateral face. Antennal 
A

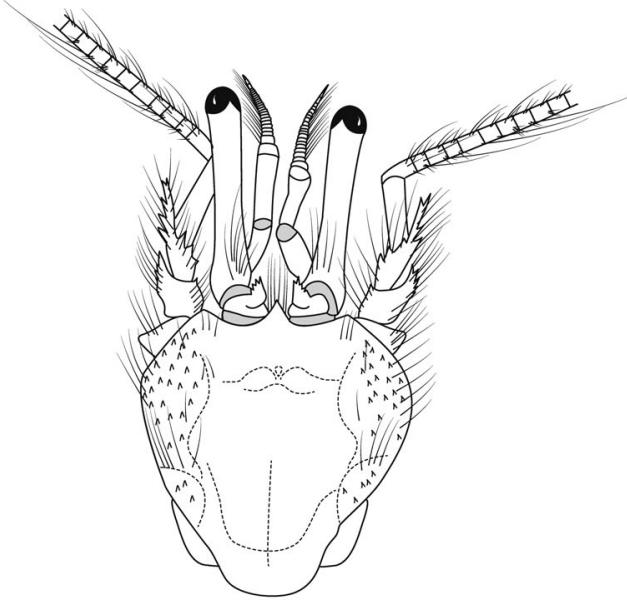

C

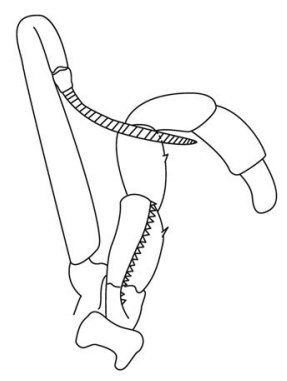

E
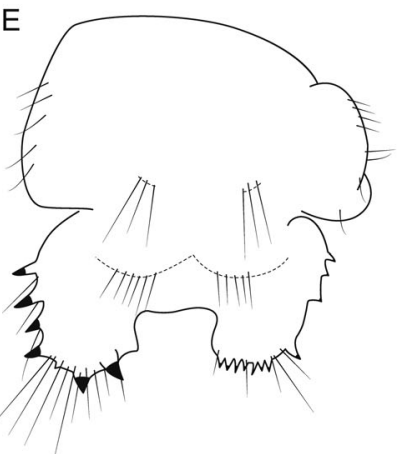
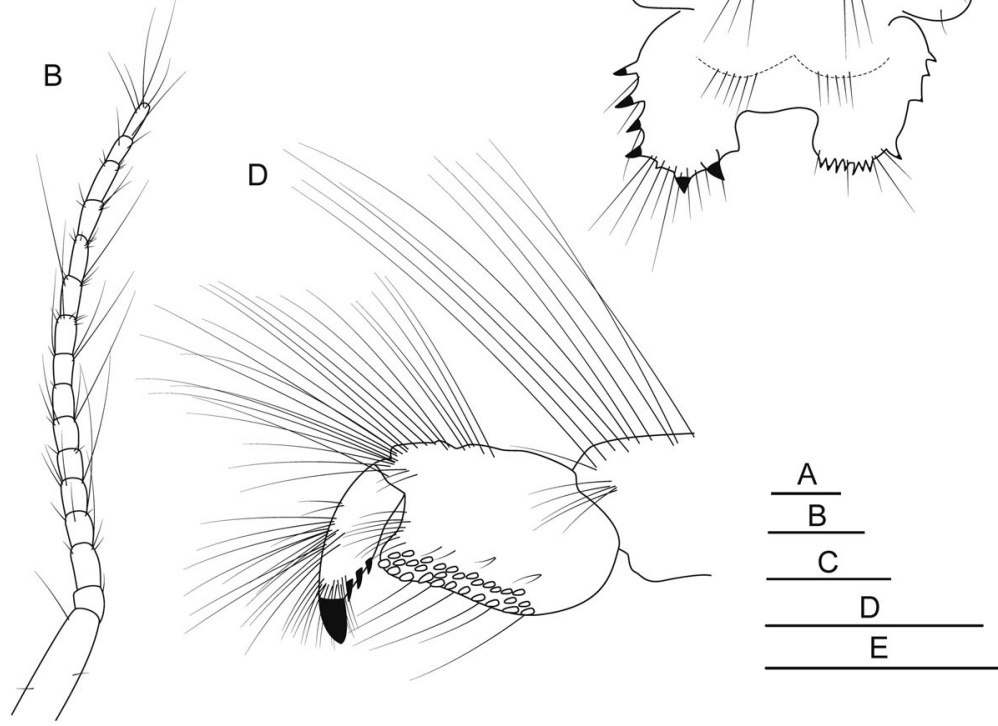

Figure 1. Paguristes scarabinoi sp. nov. A, holotype, male $4.0 \mathrm{~mm}$ (MZUSP 34621), B-E, paratype, male $3.7 \mathrm{~mm}$ (MZUSP 34625). A, shield and cephalic appendages (setae partially omitted), dorsal view; B, left antennal flagellum, mesial view; C, left third maxilliped, mesial view; $D$, left fourth pereopod, lateral view; E, telson, dorsal view. Scale bars: $1 \mathrm{~mm}$.

acicles short, not reaching distal margin of corneas, terminating in strong acute bifid spine; lateral margin with 2 or 3 acute spines, with tufts of long plumose setae, mesial margin with 2 or 3 acute spines, with tufts of long plumose setae. Antennal flagella (Figure 1B) short, not reaching cheliped palm; as long as shield length; each article with short and long setae, 3-5 setae per article, less than 1-6 articles in length.

Mandibles without distinguishing characters. Maxillule with proximal endite generally subquadrate, slightly tapered; endopod with 4 small setae on welldeveloped internal lobe, 1 small seta on internal margin proximally, external lobe very well developed, $2 / 3$ length of endopodite, slender, recurved, without small setae on exterobasal angle. Maxilla with endopodite elongate, subequal to scaphognathite in distal extension, basally inflated, tapered distally. Fist maxilliped with endopodite approximately $3 / 4$ length of exopod; exopod with basal segment moderately broad; epipodite well developed, with several marginal plumose setae. Second maxilliped with basis-ischium fusion incomplete. Third maxilliped (Figure 1C) with basis-ischium fusion incomplete; basis with 2 small spines; ischium with crista dentata well developed, consisting of about 15 spines, without accessory tooth, with small spine on ventrodistal margin; merus with 2 small spines on ventral margin and 1 small spinule on dorsodistal margin; carpus with small spine on dorsodistal margin.

Chelipeds (Figure 2A,B,C and $5 C, D$ ) with dense fringe of plumose setae on dorsolateral margins, approximately equal, left slightly stouter and shorter; armature and setation generally similar; spines on palms and carpi mostly corneous-tipped, partially obscured by 

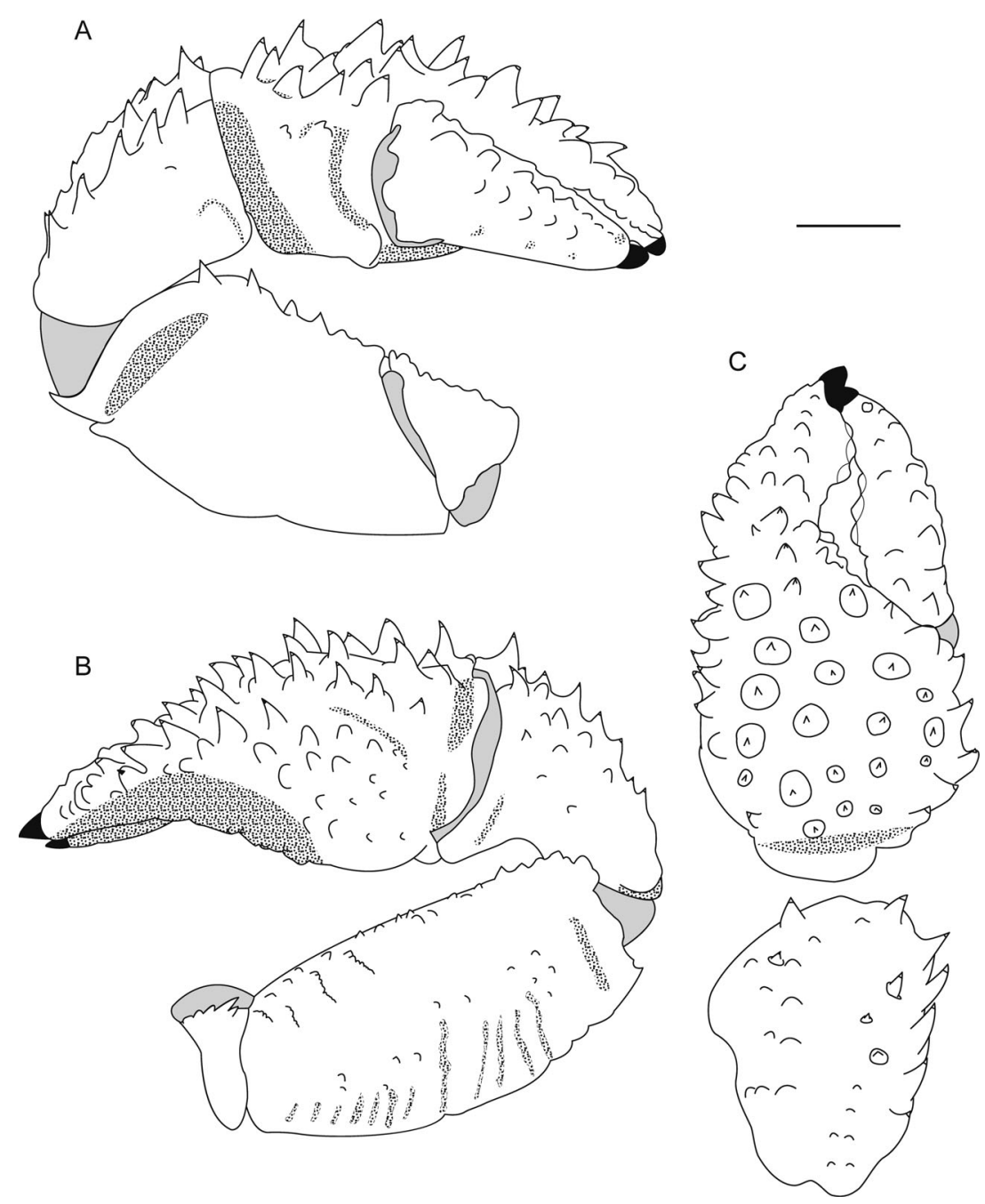

Figure 2. Paguristes scarabinoi sp. nov., paratype, male sl 3.7 mm (MZUSP 34625), left cheliped (most setae omitted). A, left cheliped, mesial view; B, same, lateral view; C, chela and carpus of same, dorsal view. Scale bar: $1 \mathrm{~mm}$.

dense tufts of plumose setae. Dactyl about 0.6 times length of palm (measured on mesial margin). Fingers leaving prominent hiatus when closed, terminating in corneous claws, crossing when closed, with fixed finger slightly overreaching dactyl; cutting edges with 3 unequal prominent calcareous teeth on proximal 2/ 3 , distal row of small fused corneous teeth (dactyl) or small calcareous teeth (fixed finger); dorsal surface of dactyl and fixed finger with longitudinal row of tubercles or spinose tubercles diminishing in size distally; fingers with tufts of moderately long plumose setae proximally; lateral margin of fixed finger well delimited by row of corneous acute spines proximally, tubercles or spinose tubercles distally. Palm about 0.5 times as long as carpus; strongly inflated ventrally; dorsomesial margin with 4 strong, corneous-tipped spines; dorsolateral margin rounded, with row of strong, corneoustipped spines; dorsal surface with scattered corneoustipped spines; lateral face spinulose, with tufts of short plumose setae; mesial face with few small spines and tufts of short setae; dorsal, dorsolateral and dorsomesial surfaces with dense tufts of long plumose setae. Carpus about 0.8 times as long as merus, with moderately dense, long plumose setae on dorsal, dorsolateral and dorsomesial surfaces; dorsal surface with scattered small and moderately sized spines or tubercles; dorsolateral surface rounded, with irregular row of small spines, dorsodistal angle with prominent corneous spine; lateral face spinulose, with scattered few long plumose setae; dorsodistal margin with 1 spine medially, with row of plumose setae; dorsomesial margin with row of strong corneous spines. Merus subtriangular; dorsal margin with row of tufts of moderately long plumose setae, lateral face spinulose or tuberculate, with tufts of long plumose setae distally; ventrolateral angle with row of blunt spines or tubercles, partially obscured by tufts of plumose setae; mesial face with vertical, 

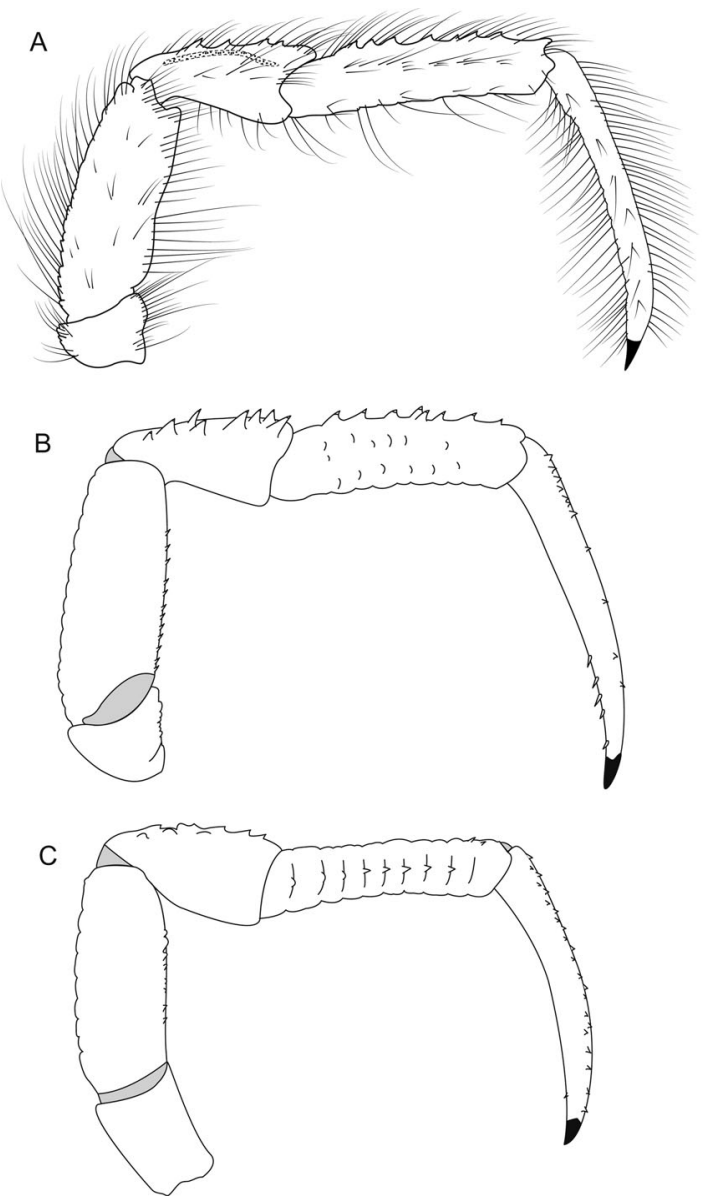

Figure 3. Paguristes scarabinoi sp. nov., paratype, male sl $3.7 \mathrm{~mm}$ (MZUSP 34625), ambulatory legs. A, right second pereopod, lateral view; B, left second pereopod, mesial view (setae omitted); C, left third pereopod, mesial view (setae omitted). Scale bar: $1 \mathrm{~mm}$.

uncalcified suture proximally, ventromesial margin with row of strong corneous spines distally, blunt spines proximally; ventral surface with dense tufts of long plumose setae; dorsodistal margin with row of 4 corneous spines medially. Ischium with spinulose ventrolateral and ventromesial margins.

Second and third pereopod (Figures 3A,B,C and 5A, $B$ ) with distinctive fringe of plumose setae bordering dorsal and ventral margins. Second pereopods overreaching chelipeds, similar between left and right. Dactyl about 1.3 times as long as propodus; slender and slightly curved; terminating in strongly arched, corneous claw; dorsal surface with row of small corneous spines, partially obscured by dense tufts of plumose setae; lateral face with longitudinal row of tufts of plumose setae; ventral margin with row of small corneous spines or spinules distally, obscured by dense tufts of long plumose setae; dorsomesial margin sometimes with corneous spinules; mesial face slightly convex without longitudinal sulcus and irregular row of corneous spinules. Propodus about twice as long as carpus; dorsal surface with row of strong spines, partially obscured by dense plumose setae; mesial face with longitudinal row of tubercles, with dense tufts of plumose setae dorsally; lateral face and ventral margin with row of long plumose setae. Carpus 0.5 times as long as merus; dorsal surface with 2 parallel rows of moderately strong corneous-tipped spines, partially obscured by dense tufts of long plumose setae; lateral face rounded, with longitudinal row of moderately long plumose setae; ventral surface with scattered long plumose setae. Merus laterally compressed; dorsal surface with row of protuberances, partially obscured by dense tufts of very long plumose setae; lateral face slightly spinulose dorsally, with scattered tufts of plumose setae; ventromesial margin with row of small spines, partially obscured by dense tufts of very long plumose setae. Ischium with long plumose setae on dorsal and ventral margin; ventrolateral and ventromesial margin spinulose.

Third pereopods similar to second, except for distinctly different armature of dactyl, propodus and carpus. Mesial face of dactyl with irregular row of small corneous spinules; dorsal surface with 1 or 2 rows of small corneous spines, partially obscured by dense tufts of plumose setae; third pereopod without row of spinules on ventral surface, rarely few spinules distally. Dorsal surface of propodus without row of strong spines, with irregular row of small distal spinules proximally; mesial face with longitudinal irregular row of corneous spinules. Dorsal surface of carpus with single row of small corneous-tipped spines.

Fourth pereopod (Figure 1D) semichelate. Dactyl broadly curved, slender, subtriangular, terminating in sharp corneous claw, with ventrolateral row of small corneous teeth, preungual process not apparent. Propodus, carpus, merus and ischium unarmed, with dense tufts of very long, plumose setae on ventral and dorsal surfaces. Propodal rasp consisting of 2-4 rows of small ovate corneous scales.

Fifth pereopod chelate. Dactyl and propodus with tufts of long simple setae on dorsal surfaces; ventral surfaces with dense tuft of long simple setae; propodal rasp covering 1/4 of lateral face of segment. Carpus, merus and ischium with tufts of simple and plumose long setae on dorsal and ventral surfaces.

Pleon dextrally twisted. Male with paired first and second pleopods (Figure $4 A, B, C$ ) modified as gonopods, and unpaired left third to fifth pleopods. Male first pleopod twisted (Figure $4 A, B$ ); with row of long stiff setae on mesial margin of basal lobe; tuft of few long setae present on lateral margin of basal lobe; inferior lamella broad, with double row of 


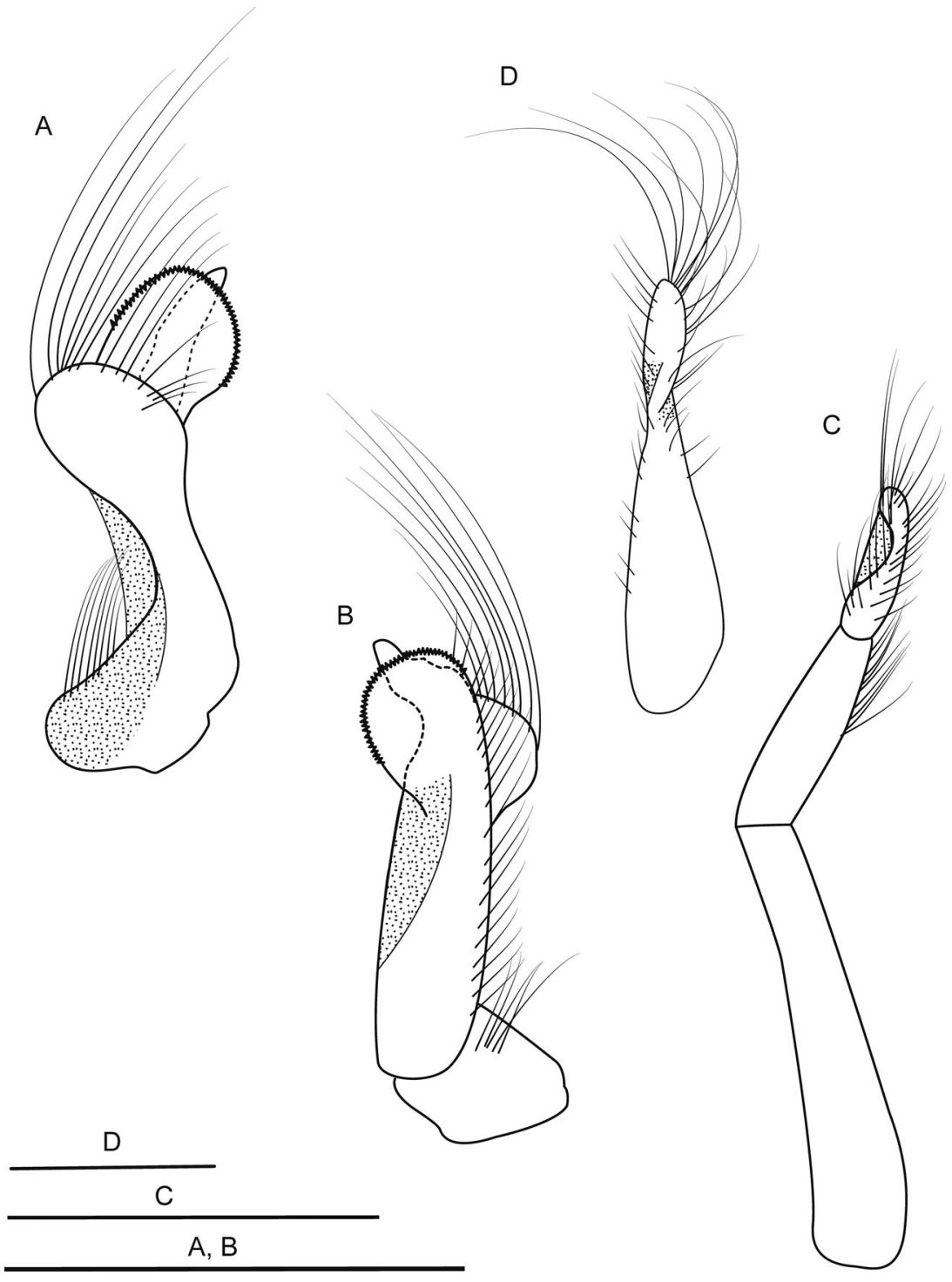

Figure 4. Paguristes scarabinoi sp. nov. paratypes, A-C, male sl $3.7 \mathrm{~mm}$ (MZUSP 34625), D, female sl $2.4 \mathrm{~mm}$ (MNHN-IU-201412855). A, left first gonopod, dorsal view; $B$, same, ventral view; $C$, left second gonopod, ventral view; $D$, female brood pouch, lateral view. Scale bars: $1 \mathrm{~mm}$.

small hooked spines on rounded margin, followed by row of moderately long setae on lateral margin; internal lobe with rounded distal portion, with 1 or 2 rows of dense short to long setae on distal margin and inner surface; external lobe relatively slender, slightly overreaching distal margin of inferior lamella, glabrous. Second pleopod (Figure 4C) with basal segment usually glabrous, occasionally with few, scattered, short plumose setae; distal segment with row of few moderately long setae on mesial margin, distal angle with tuft of long setae; appendix masculina with moderately long to long setae on distal margin and inferior face. Left third to fifth pleopods with exopods moderately developed, endopods absent or vestigial.
Female with paired first pleopods, modified as gonopods; basal lobe glabrous, distal lobe with margins slightly serrate, with long plumose setae. Left second to fourth pleopods with both rami well developed, ovigerous. Fifth pleopod with exopod well developed, endopod vestigial or absent. Brood pouch (Figures 4D and 5E) elongate, slender, blade-shaped, with long plumose setae on distal margin.

Telson (Figure 1E) with posterior lobes slightly asymmetrical, left lobe larger and with stronger spines; lateral indentations present; median cleft deep; right and left terminal margins with 6 or 7 small spines, increasing in size laterally, extending onto lateral margin, with long setae; anterior lobe unarmed, with tuft of moderately long setae on lateral margin. 


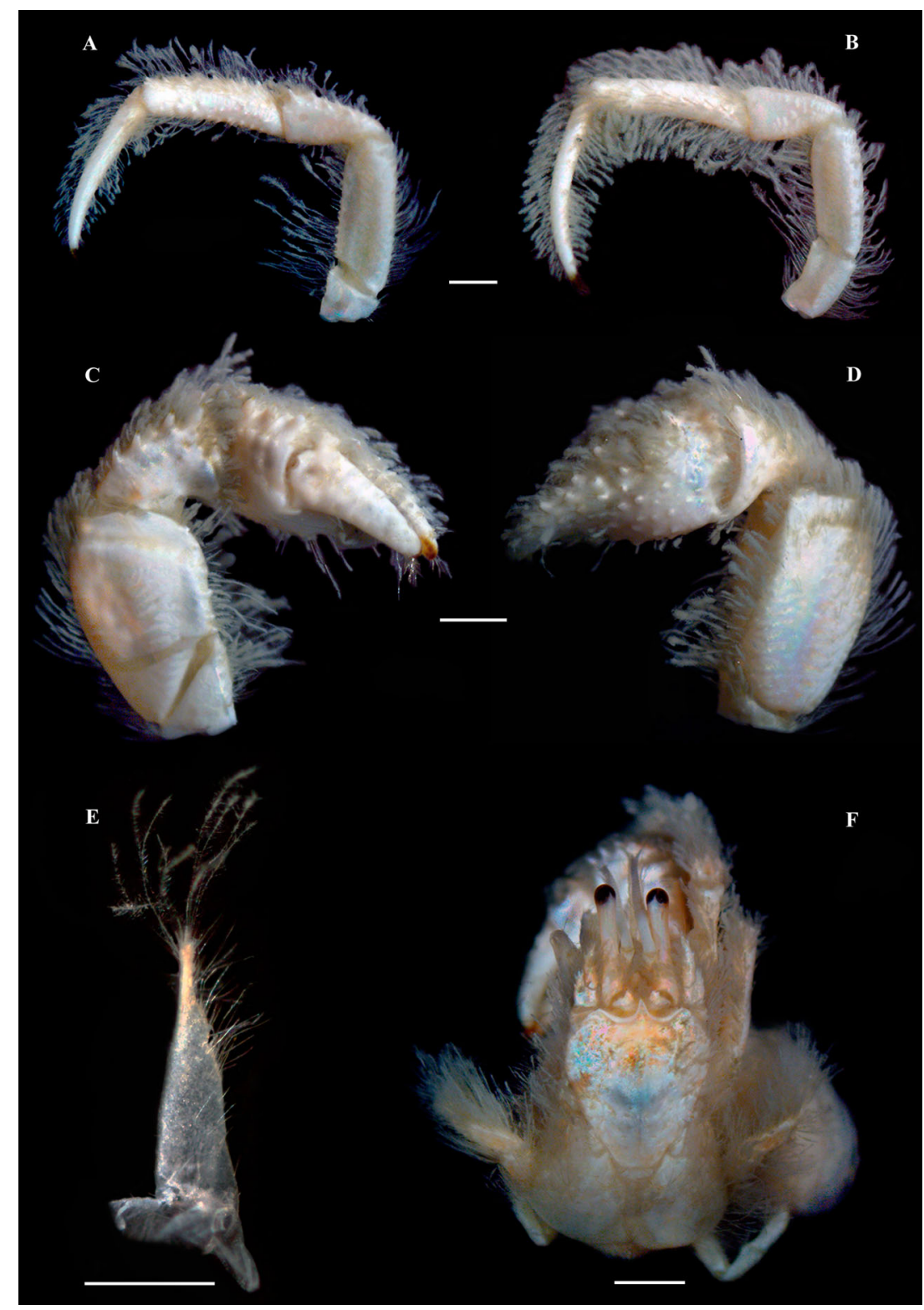

Figure 5. Paguristes scarabinoi sp. nov. paratypes, A-D, male sl $2.6 \mathrm{~mm}$ (MZUSP 34625), E, female sl $2.4 \mathrm{~mm}$ (MNHN-IU-201412855), F, male sl. $3.2 \mathrm{~mm}$ (MZUSP 34625). A, right second pereopod, mesial view; B, right third pereopod, mesial view; C, left cheliped, mesial view; D, left cheliped, lateral view; E, female brood pouch, lateral view; F, shield and cephalic appendages, dorsal view. Scale bars: $1 \mathrm{~mm}$.

\section{Colouration}

In preservative: shield, pereopods, antennal and ocular peduncle pale orange.

\section{Distribution}

So far known only from type locality, off Uruguay, between $35^{\circ} 41^{\prime} 7^{\prime \prime} \mathrm{S}-52^{\circ} 35^{\prime} 6^{\prime \prime} \mathrm{W}$ and $34^{\circ} 43^{\prime} 1^{\prime \prime} \mathrm{S}-52^{\circ}$ $37^{\prime} \mathrm{W}$; at depths of $66-68 \mathrm{~m}$.

\section{Etymology}

This new species is named in honour of the collector of the material, Fabrizio Scarabino, for his dedication to the study of the marine and estuarine invertebrates of Uruguay.

\section{Comparisons}

Of the seven species originally assigned by McLaughlin \& Provenzano (1974) to the Paguristes tortugae complex, two have been subsequently transferred to other genera by Lemaitre \& Felder (2012): P. hewatti Wass, 1963 to Areopaguristes Rahayu \& McLaughlin, 2010 and P. invisisacculus McLaughlin \& Provenzano, 1974 to Pseudopaguristes McLaughlin, 2002; these transfers were based primarily on the gill formula 
(Komai et al. 2015). Paguristes scarabinoi sp. nov. clearly belongs to the $P$. tortugae complex because of the presence of a characteristic dense fringe of plumose setae bordering the ambulatory legs and the dorsolateral margins of the chelipeds. Paguristes scarabinoi sp. nov. can be distinguished from almost all other species of the $P$. tortugae complex by the presence of distinctly long setae, reaching 6 articles in length on the antennal flagellum; in contrast, $P$. tortugae, $P$. perplexus, $P$. hernacortezi, $P$. anomalus, $P$. werdingi and $P$. zebra all have short setae, not overreaching 3 articles in length. Long setae on the antennal flagellum in $P$. scarabinoi sp. nov. are also found in $P$. maclaughlinae and P. angustithecus. However, the new species may be separated from the former species by the presence of antennular peduncles that are short to moderately long, reaching to about onethird of the size of the ocular peduncles including the corneas, whilst in P. maclaughlinae, the antennular peduncles are very long, more than twice the length of the ocular peduncles including the corneas, and from the latter species by the presence of a long, slender dactyl, without a longitudinal sulcus flanked by corneous spines or spinules on the mesial margin on the ambulatory legs, whereas $P$. angustithecus has a short, usually stout dactyl with a longitudinal sulcus proximally, and 1-3 single or double rows of corneous spines or spinules on the mesial margins of the ambulatory legs. Additionally, $P$. scarabinoi sp. nov. differs from $P$. angustithecus in the dorsal surface of the third pereopod presenting very small spinules only distally, while in $P$. angustithecus a row of small corneous spines or spinules is present along the entire length of the dorsal surface of the third pereopod. Paguristes scarabinoi sp. nov. can also be separated from $P$. angustithecus and $P$. tortugae, by the pale orange ocular peduncles in preserved condition, without the banding pattern that is characteristic of the latter two species.

Apart from $P$. scarabinoi sp. nov. only two other Paguristes species have been recorded in the temperate south-western Atlantic, south of $34^{\circ} \mathrm{S}$ : $P$. robustus Forest \& de Saint Laurent, 1968 and P. foresti Scelzo, 1971 (Forest \& de Saint Laurent 1968; Scelzo \& Boschi 1973; Boschi et al. 1992; Scarabino 2006). However, these two species do not belong to the $P$. tortugae complex as they do not possess the characteristic dense fringe of plumose setae on the pereopods and chelae. Paguristes scarabinoi sp. nov. differs from $P$. robustus in having an elongated blade-shaped brood pouch; the brood pouch is subrectangular in $P$. robustus. The new species can be distinguished from $P$. foresti by the differential armature of the carpus, the propodus of the ambulatory legs, and the setation of the antennal flagellum. Paguristes scarabinoi sp. nov. has a row of strong corneous spines on the dorsal surface of the carpus of the third pereopod, and the ventral surface of the propodus of the second pereopod is unarmed, with a row of protuberances along the propodus length, whereas $P$. foresti has only one spine on the dorsal surface of the carpus of the third pereopod and a row of corneous spines on the ventral surface of the propodus of the second pereopod. Furthermore, P. scarabinoi sp. nov. has long setae on the antennal flagellum, whereas $P$. foresti has short setae.

One morphological feature shown to be constant and diagnostically significant for species of Paguristes sensu stricto is the shape of the brood pouch in females (McLaughlin \& Provenzano 1974). Paguristes scarabinoi sp. nov. and $P$. angustithecus share an elongate, blade-shaped brood pouch, which in the other species of the $P$. tortugae complex has a rather different shape, e.g. elliptical and weakly bilobed in $P$. zebra; subtriangular in $P$. perplexus; large, subovate or subquadrate in $P$. tortugae and $P$. maclaughlinae; small and subquadrate in $P$. hernancontezi; and absent in $P$. anomalus.

\section{Key to the western Atlantic species of the Paguristes tortugae complex}

1. Anterior lobes of telson bearing 4 spines on distolateral angle; distal portion of ocular peduncles dark blue .................. P. werdingi Anterior lobes of telson ranging from unarmed to 3 spines on distolateral angle; anterior lobes of telson rarely with 4 spines, but when present, ocular peduncles mottled pale orange ..........2

2. Articles of antennal flagella with setae of $6-8$ articles in length $\ldots \ldots \ldots \ldots \ldots \ldots \ldots \ldots \ldots \ldots \ldots$ Articles of antennal flagella with setae of 1-3 articles in length $\ldots \ldots \ldots \ldots \ldots \ldots \ldots \ldots \ldots \ldots \ldots \ldots \ldots \ldots$

3. Antennular peduncles more than twice length of ocular peduncles including corneas; female brood pouch subovate or subquadrate ........P. maclaughlinae Antennular peduncles reaching to about $1 / 3$ length of ocular peduncles including corneas; female brood pouch elongate, blade-shaped ...........4

4. Dactyl of ambulatory legs stout, longer than propodus, without longitudinal sulcus on mesial surface; third pereopod propodus without row of corneous spines on dorsal surface ..........P. scarabinoi sp. nov. Dactyl of ambulatory legs slender, smaller than propodus, with horizontal sulcus proximally on 
mesial surface; third pereopod propodus with single or double, irregular rows of small spines or spinules P. angustithecus

5. Dorsal surface of third pereopod merus unarmed

$\ldots \ldots \ldots \ldots \ldots \ldots \ldots \ldots \ldots \ldots \ldots \ldots \ldots$

Dorsal surface of third pereopod merus with at least 1 row of small spines or spinulose protuberances ......................

6. Ocular acicles with one bifid terminal spine; ocular peduncles striped, with distinct zebra-like irregular dark bands ................... zebra Ocular acicles usually with one terminal spines, rarely with one additional small spine laterally; ocular peduncles not striped, uniformly reddishorange ................ perplexus

7. Shield with dorsolateral surface and margins armed with numerous small spines or spinulose tubercles; ocular peduncles with distinct, often irregular dark bands distally .............. P. tortugae Shield with dorsolateral surface and margins unarmed or with few, minute spinules; ocular peduncles without distinct dark bands ........8

8. Dorsal margin of merus of cheliped unarmed P. hernancortezi Dorsal margin of merus of cheliped armed with spinules or spinulose protuberances ....P. anomalus

\section{Acknowledgements}

We are grateful to Fabrizio Scarabino (CURE-Centro Universitario Regional Este) and Dr Marcos Tavares (MZUSP) for providing working space and/or access to their collections. We express our thanks to the crew of the R/V 'Aldebaran' 2005-04 cruise, as well as to the Direccíon Nacional de Recursos Acuáticos (DINARA, Uruguay). We also thank the Universidade do Sagrado Coração (USC) for supporting studies on the systematics of decapod crustaceans, and Dr Arthur Anker for his comments on the manuscript and great help with the English language The authors are grateful for the cooperation, assistance, and insightful comments provided by Dr Rafael Lemaitre (USNM), which considerably improved this manuscript and our knowledge about the group. Thanks also to Joana d'Arc (MZUSP) and Maria José Souza Coelho (MZUSP) for their kind assistance throughout the execution of this work.

\section{Funding}

This work was supported by a Conselho Nacional de Desenvolvimento Científico e Tecnológico (CNPq) PhD fellowship [162247/2013-3] to DL, and by a grant from the Fundação de Amparo à Pesquisa do Estado de São Paulo (FAPESP) to WS [grant no. 2013/1201-0].

\section{Disclosure statement}

No potential conflict of interest was reported by the authors.

\section{ORCID}

Daniel José Marcondes Lima (D) http://orcid.org/0000-00023039-9134

William Santana (D) http://orcid.org/0000-0003-3086-4419

\section{References}

Boschi E, Fischbach CE, lorio MI. 1992. Catálogo ilustrado de los crustáceos estomatópodos y decápodos marinos de Argentina. Frente Marítimo 10(A):7-94.

Forest J, de Saint Laurent M. 1968. Résultats scientifiques des campagnes de la "Calypso", Part VII. Campagne de la Calypso au large des côtes Atlantiques de l'Amérique du Sud (1961-1962). 6. Crustacés Décapodes: Pagurides. Annales de I'Institut Océanographique de Monaco, N.S. 45(2):45-172.

Komai T, Reshmi R, Kumar AB. 2015. A new species of the hermit crab genus Paguristes Dana, 1851 (Crustacea: Decapoda: Anomura: Diogenidae) from southwestern India. Zootaxa 3937(3):517-32. doi:10.11646/zootaxa.3937.3.5

Lemaitre R, Felder D. 2012. A new species of the hermit crab genus Areopaguristes Rahayu \& McLaughlin, 2010 (Crustacea: Decapoda: Anomura: Diogenidae) discovered in the Mesoamerican Barrier Reef of Belize, Caribbean Sea. Zootaxa 3480:67-79.

Lemaitre R, Tavares M. 2015. New taxonomic and distributional information on hermit crabs (Crustacea: Anomura: Paguroidea) from the Gulf of Mexico, Caribbean Sea, and Atlantic coast of South America. Zootaxa 3994(4):451506. doi:10.11646/zootaxa.3994.4.1

McLaughlin PA, Provenzano Jr AJ. 1974. Hermit crabs of the genus Paguristes (Crustacea: Decapoda: Diogenidae) from the Western Atlantic. Part I. The Paguristes tortugae complex, with notes on variation. Bulletin of Marine Science 24(1):165-234.

McLaughlin PA, Provenzano Jr AJ. 1975. Hermit crabs of the genus Paguristes (Crustacea: Decapoda: Diogenidae) from the Western Atlantic. Part II. Descriptions of six new species. Bulletin of Marine Science 24(4):885-938.

Provenzano Jr AJ. 1959. The shallow-water hermit crabs of Florida. Bulletin of Marine Science of the Gulf and Caribbean 9:349-420.

Scarabino F. 2006. Faunística y taxonomía de invertebrados bentónicos marinos y estuarinos de la costa uruguaya. In: Menafra R, Rodríguez-Gallego L, Scarabino F, Conde D, editors. Bases para la Conservación y el Manejo de la Costa Uruguaya. Montevideo: Vida Silvestre, p 113-42.

Scelzo MA, Boschi EE. 1973. Aportes al conocimiento de la distribución geográfica de los crustáceos decápodos Anomura del Atlántico Sudoccidental, frente a las costas argentinas. Trabajos del V Congresso Latinoamericano de Zoología 1:204-16.

WoRMS Editorial Board. 2016. World Register of Marine Species. http://www.marinespecies.org (accessed 19 July 2016). 